\title{
The Capitalization of Coupled and Decoupled CAP Payments into Land Rental Rates
}

\author{
STEPHEN O’NEILL ${ }^{\dagger \ddagger}$ and KEVIN HANRAHAN ${ }^{\ddagger}$ \\ †Department of Economics, National University of Ireland, Galway, Ireland \\ *Rural Economy Research Centre (RERC), Teagasc, Ireland \\ Contact: stepheno neill 1999@yahoo.com
}

1) P a g e 


\begin{abstract}
:
This paper explores the extent to which payments under the Common Agricultural Policy (CAP) are capitalized into land rents in Ireland with implications for the transfer efficiency of such payments, since subsidies may not benefit targeted recipients if they are capitalized into input prices. Capitalization in the years preceding and following the 'decoupling' of agricultural support payments from agricultural production is explored. In the period prior to decoupling, direct support (Pillar 1) payments were highly capitalized into Irish agricultural rents (67 to 90 cents per euro of subsidies), while in the post decoupling period capitalization appears to have declined somewhat.
\end{abstract}

\title{
JEL Classification: Q24, Q10
}

Keywords: land, rent, decoupling, Sytem-GMM, dynamic. 


\section{Introduction}

The agricultural sector in the EU, as in the US, is heavily subsidised. Appropriations dedicated to the Preservation and Management of Natural Resources accounted for $€ 60.2 \mathrm{bn}$ or $39.8 \%$ of the 2013 EU budget. ${ }^{1}$ These appropriations are mainly devoted to financing the Common Agricultural Policy (CAP) and the Common Fishery Policy (CFP), with the CAP accounting for over $70 \%$ of spending. ${ }^{2}$ Initially, agricultural incomes were supported via market supports, however the endemic over-production that resulted lead to the MacSharry Reforms agreed in 1992. These reforms were comprised of reductions in intervention prices for meat and cereals which were offset by increased direct payments. However, since these payments were linked to current production outcomes, they continued to distort production decisions and hence input use, as farmers sought to increase their subsidy receipts.

Given the incentive to increase production and the associated increase in input demand, one would expect upwards pressure on input prices, particularly for inputs with relatively inelastic supply such as land (Floyd, 1965; Hertel, 1989; Ciaian and Swinnen, 2006). This has important implications for the transfer efficiency of subsidies since the portion of subsidies that is bid into input prices is not reaching its intended recipient. As a result the capitalization of subsidies into input prices, particularly land prices, has attracted considerable attention in the literature (Phipps, 1984; Featherstone and Baker, 1987; Barnard, et al., 1997; Weersink et al., 1999; Shaik et al., 2005 inter alia). More recently attention has focussed on land rental rates (Lence and Mishra, 2003; Roberts et al. 2003; Kirwan, 2005, 2009 inter alia).

\footnotetext{
${ }^{1}$ http://ec.europa.eu/budget/figures/2013/2013 en.cfm accessed 1st October 2013.

2 http://ec.europa.eu/budget/figures/interactive/index en.cfm accessed 1st October 2013.

3 | P a g e
} 
Concerns regarding the potential for coupled support payments to distort production and trade, in addition to the impending enlargement of the EU, led to the Mid-Term Review of the CAP (or Fischler reforms) agreed in 2003. These reforms sought to replace payments based on current production with payments based on past production decisions, referred to as "decoupled" payments since they are no longer coupled to current production. To the extent that coupled subsidies are bid into non-land inputs, one may anticipate that a move to decoupled subsidies would increase land values since there is no requirement to actually produce, freeing farmers from the need to purchase non-land inputs. The inelastic supply of land, in conjunction with the requirement to possess land to claim full decoupled payments, may increase the capitalization of subsidies into rents.

Although decoupled payments in the EU and the US are tied to the possession of land, the specifics differ across the two regions. In the US, the Federal Agriculture Improvement and Reform (FAIR) Act in 1996, removed the link between income support payments and production, through the introduction of Production Flexibility Contracts (PFC) payments which are independent of the type, quantity and the market price of crops grown (Guyomard, Bureau, Gohin and Le Mouël, 2000). The PFC payments were tied to specific plots of land and therefore land transfers directly resulted in transfers of subsidies between farms. This is likely to increase the capitalization of these decoupled payments into land values. In contrast, in the EU decoupled payments under the Single Payment Scheme (SPS) require that farmers be in possession of a specified number of hectares (based on activities during the reference period 2000-2002) to obtain a full SPS payment, but importantly there is no requirement that the farmed area comprise of the same parcels in each period. Hence, under the SPS, farmers 4I Pag e 
in the EU have greater flexibility to trade land (e.g. via land rental markets) while maintaining their SPS payment and this may be anticipated to reduce capitalization of subsidies into land values.

However, subsidies that are ostensibly decoupled from production may still influence production decisions, for example due to wealth and insurance effects (Hennessy, 1998; Rude, 2000), by improving access to credit (Vercammen, 2003) or by changing farmers' labour supply (Guyomard et al., 2004). Furthermore, since decoupled payments vary less over time they may be more readily capitalized into input prices. Where decoupled payments are based on historical production decisions, there may also be an incentive for farmers to maintain increased production levels if they expect the basis on which payments are made to be updated to include the current period at some future point in time (OECD, 2001; Westcott and Young, 2002). Therefore decoupled payments may continue to be partially capitalized into non-land input prices, reducing the extent to which they are bid into land values.

This paper adds to the burgeoning literature on capitalization of subsidies into land rents by exploring the extent to which coupled and decoupled subsidy payments have been capitalized into land rental rates in Ireland using panel data from the Teagasc National Farm Survey for the years 2000 to 2009 encompassing both the period preceding the move to decoupled payments and the four years after their introduction. In Ireland, all direct payments for cattle, sheep and arable crops as well as future dairy compensation payments would be fully decoupled from production as of 1 January 2005. Also, the vast majority of farms rent land under the conacre system which consists of short term loans, usually of 11 months duration (Patton et al., 2008; O'Neill and Hanrahan, 2012). Thus rental contracts are 5| Page 
renegotiated regularly implying that the effects of policy changes on rents should be more apparent in Ireland than in countries where multi-year contracts are prevalent.

Additionally, the implementation of the SPS recognised that a requirement to possess a specific amount of land, based on the area farmed during the reference period, would have created serious difficulties for farmers whose rental agreements had expired. To combat this, an option to "consolidate" entitlements was offered (DAF, 2004). The consolidation option meant that farmers whose land rental agreements had expired could effectively transfer payments from areas which they no longer rented, to land which they still possessed. ${ }^{3}$ These farmers were then required to maintain an area equal to the portion of their declared land for which the rental agreements had not expired. Farmers that have exercised the consolidation option may effectively no longer have a requirement to rent-in land to satisfy the SPS land requirement or at least have a reduced demand for rented in land. Hence the land requirement is less binding in Ireland than in other European countries due to the "conacre" system of short term land rental agreements in operation. The ratio of eligible land to the number of entitlements is a key driver of the capitalization rate (Courleux et al. 2008; Ciaian, Kancs, and Swinnen, 2008; Michalek et al. 2014) so consolidation would be anticipated to lead to a reduction in capitalization.

Given the prevalence of short term contracts in Ireland, many farmers had the option of consolidating their entitlements and hence it is anticipated that capitalization should be low in Ireland compared to other EU countries. In essence, many farmers in Ireland are in a

\footnotetext{
${ }^{3}$ Under the consolidation option farmers with entitlement established in part or in full on rented-in land could reduce the area used to claim their entitlement by a maximum of $50 \%$. The value of each entitlement ( $€ / \mathrm{ha})$ is increased following consolidation so that total farmer receipts from the SPS were unaffected.

6I P a g e
} 
position to 'escape' from situations where significant portions of their subsidies are being captured by landowners by consolidating their entitlements. Combined with the tradability of entitlements, consolidation moves the decoupled SPS payment in Ireland in the direction of a bond scheme (Swinbank and Tangerman, 2001; Swinbank and Tangermann, 2004) and would be expected to increase the transfer efficiency of the decoupled subsidies. Thus if coupled payments were previously heavily capitalized into rents, a decline in rents is anticipated.

This research has important policy implications since the greater the incidence of subsidies on rents, the less of the subsidy that reaches the targeted recipient and hence the less impact the policy has on the farm incomes of this group. Indeed, to the extent that land is owned by non-farmers or farmers engaged in unsupported production types (e.g. growing fruit and vegetables), the subsidy may not even reach the intended sector. Furthermore, since land is a fundamental requirement for agricultural production to occur, increased land rents/prices may represent significant barriers to entry into the agricultural sector and may also impede restructuring within the sector (Karlsson and Nilsson, 2014). This final consideration is likely to be very important in an Irish context as a very low proportion of agricultural land is transacted on an annual basis, and the principal route through which structural change in Irish agriculture is likely to occur is via the agricultural land rental market.

The findings suggest that coupled subsidies for dairy, sheep and tillage farms are capitalized into land values with 77 cents, 67 cents and 90 cents of each euro of support being bid into rents respectively in the long run. For cattle farms the point estimate suggests 54 cents per euro of support is bid into rents although this is not statistically different from zero. Thus a 7|Page 
considerable proportion of CAP supports accrue to landowners in the form of higher rents rather than to the intended recipients. Hence the transfer efficiency of pre-decoupling CAP payments appears to be low. Following the Fischler reform, there appears to have been a reduction in the extent of capitalization while landowners still capture a sizable share of pillar 1 support payments.

\section{Background}

Much of the existing literature on the capitalization of subsidies into rental rates has focussed on the US with considerable variation in the estimated incidence both across studies and across support payment types. In the context of the FAIR Act, Lence and Mishra (2003) explore the impact of the PFC and Market Loss Assistance (MLA) payments, which are decoupled from production, finding that they are almost completely bid into land rents, while other payment types are not capitalized. However, a series of papers by Kirwan and colleagues (Roberts, Kirwan and Hopkins, 2003; Kirwan 2009; Kirwan and Roberts, 2010) report considerably lower incidence, with between 34 and 41 cents per dollar of PFC support were bid into rents (Roberts, Kirwan and Hopkins, 2003). Similarly, Kirwan (2009) finds that following the introduction of unanticipated MLA payments, 34 cents per dollar of support is bid into rents. Using field level data, Kirwan and Roberts (2010) find that between 14 and 24 cents of the marginal subsidy dollar are bid into land rents.

The type of rental contract also impacts on capitalization with landowners capturing a greater share of support under crop-share contracts (86\%) than under cash leases (38\%) (Qiu, Gervais and Goodwin, 2010). The potential impact of reforms to support programmes 
on capitalization is illustrated by Woodard, Paulson, Baylis and Woodard (2010) who report that prior to the Farm Security and Rural Investment (FSRI) Act of 2002 only 8 cents per dollar of support was capitalized into Illinois rents, rising to 47 cents per dollar following the FSRI Act. ${ }^{4}$

The capitalization of CAP payments into European land rents has received relatively little attention until quite recently. Early work by Fuchs (2002), found relatively low capitalization of subsidies into rents with approximately 7 cents per additional euro of subsidies bid into rents. In an Irish context, Patton et al. (2008) explore the capitalization of the pre-Fischler reform payments into land rents in Northern Ireland using data from the Farm Business Survey from 1994 to 2002. Rental contracts in Northern Ireland are based on the 'conacre' system (as are those in the Republic of Ireland considered here). Patton et al. (2008) find that coupled subsidies such as the special beef premium ( 41 pence per $€ 1$ of subsidies) and suckler cow premium ( 42 pence per $£ 1$ of subsidies) are heavily capitalized into agricultural land rents, while the ewe premium is fully capitalized into land rents. ${ }^{5}$ The hill-livestock compensation allowance (58 pence per $£ 1$ of subsidies) and less favoured area payments ( $£ 1.20$ per $1 £$ of subsidies) are also found to be heavily bid into rents.

This capitalization of coupled subsidies is in keeping with the results of Breustedt and Habermann (2011) who estimate a spatial econometric model for rents and find that an additional euro of premium payments increases rents by 38 cents using data for the German

\footnotetext{
${ }^{4}$ The FSRI Act introduced Counter-Cyclical Payments (CCPs) to replace the ad-hoc MLA payment and, more significantly, allowed producers to update their historical acreage and yield information on which PFC payments were made according to planting during the post-1996 periods. The reader is referred to Sumner (2003) and Kirwan (2009) for a detailed discussion of the changes introduced under the FSRI Act.

${ }^{5}$ The greater capitalization of sheep payments is attributed to the fact that sheep production requires few inputs besides land, limiting the extent to which other factors of production capture these subsidies.
}

9 | P a g e 
federal state of Lower Saxony in 2001. Ciaian, Kancs and Michalek (2011) apply a generalized propensity score matching estimator to a balanced panel of FADN data for the EU-15 from 2004 to 2007. Considerable variation in capitalization is observed across countries ranging from 2 percent in Denmark and Greece to 11 percent in Spain when averaged across all farms, although capitalization is also found to vary within countries across different farm sizes. Following the enlargement of the EU, a Single Area Payment Scheme (SAPS) was introduced for the new EU Member States consisting of flat-rate payments per hectare. ${ }^{6}$ Ciaian and Kancs (2012) find that between 18 and 20 cents per euro of SAPS payments are bid into land rents. Surprisingly, Moro, Guastella, Sckokai and Veneziani (2013) find that neither the coupled or decoupled subsidies exert a significant effect on agricultural land rents using FADN data for field cropping farms in Italy from 1994 to 2008.

The literature discussed above assume that the rent set in a particular year does not depend directly on the rent prevailing in previous years. One exception to this is Hendricks, Janzen and Dhuyvetter (2012) who apply a dynamic System-GMM approach, similar to that adopted here, to Kansas land rents, finding a short-run (long run) capitalization of subsidies into agricultural rents of 12 cents ( 37 cents). The coefficient for lagged rents is found to be 0.675 , indicative of considerable inertia in rental rates and broadly in line with the inertia exhibited by Irish rents (as discussed below).

\footnotetext{
${ }^{6}$ The new Member States are Czech Republic, Estonia, Latvia, Lithuania, Hungary, Poland and Slovakia.
} 10 | P a g e 


\section{Methodology:}

The canonical approach to estimating the capitalization of subsidies assumes that the rental rate per hectare paid by farm $i$ in period $t$ ( $\mathrm{R}_{\mathrm{it}}$ ) can be expressed as a function of expected market-based returns $\left(\mathrm{M}_{\mathrm{it}}\right)$ and the expected levels of the various government subsidies $\left(\mathrm{G}_{\mathrm{it}}\right)^{7}$

$$
R_{i t}=\alpha+\beta E\left[M_{i t}\right]+\omega E\left[G_{i t}\right]
$$

It should be noted that $M_{i t}$ here refers to market income before land rents are subtracted. As discussed by Hendricks et al. (2012), the rental rate paid by a farmer in a particular year may in part depend on the rental rate paid by the farmer in the previous period - this is particularly likely where land is rented for periods in excess of a year. While the system of agricultural land rental in Ireland is predominantly short term 'conacre' rentals, anecdotal evidence suggests that there is considerable inertia in rent setting by farmers in Ireland, with farmers tending to rent the same plot in multiple years without renegotiating the rent paid annually. Allowing for time invariant unobserved heterogeneity $\left(\mu_{\mathrm{i}}\right)$ and including a random error term leads to the econometric model in [2]:

$$
R_{i t}=\gamma R_{i t-1}+\alpha+\beta E\left[M_{i t}\right]+\omega E\left[G_{i t}\right]+\mu_{i}+\varepsilon_{i t}
$$

The long run effect of market returns and government subsidies are given by $\frac{\beta}{(1-\gamma)}$ and $\frac{\omega}{(1-\gamma)}$ respectively (Hendricks et al., 2012). Since the farmers' expectations regarding market returns and subsidies are in general unobserved, in the literature it is common to use realised

\footnotetext{
${ }^{7}$ For instance Roberts, Kirwan and Hopkins (2003) state that "Economic Theory implies that land rents should equal expected returns less payments for factors besides rents".
}

11 I P a g e 
values in place of expectations, while allowing for the fact that this introduces expectation error, which is akin to measurement error (Lence and Mishra, 2003; Roberts et al., 2003; Patton et al. inter alia). The expectation error associated with market returns is denoted $\varepsilon^{\mathrm{M}}$, while the expectation error for government subsidies is denote $\varepsilon^{\mathrm{G}}$. Equation 2 can be rewritten:

$$
\begin{aligned}
R_{i t} & =\gamma R_{i t-1}+\alpha+\beta M_{i t}+\omega G_{i t}+\mu_{i}+\varepsilon_{i t}-\beta \varepsilon_{i t}^{M}-\omega \varepsilon_{i t}^{G} \\
& =\gamma R_{i t-1}+\alpha+\beta M_{i t}+\omega G_{i t}+\mu_{i}+v_{i t}
\end{aligned}
$$

The estimation of equation [3] will lead to a bias in the estimated coefficients unless expectation error is accounted for. To see this, consider two identical farmers, A and B with similar expectations regarding their income per hectare so that they should be willing to pay the same rental rate $\left(R^{A}=R^{B}\right)$. If farmer $A^{\prime} s$ realised market return is greater than expected, then $\mathrm{M}^{\mathrm{A}}>\mathrm{M}^{\mathrm{B}}$ but $\mathrm{R}^{\mathrm{A}}=\mathrm{R}^{\mathrm{B}}$. The econometrician would base estimates of the effect of income on rents on the variation of realised income $\left(\mathrm{M}^{\mathrm{A}}-\mathrm{M}^{\mathrm{B}}\right)$ rather than the variation in expected income which is 0 in this example, leading to a biased estimate. Mathematically, we can express this bias as: $\operatorname{plim} \hat{\beta}=\frac{\operatorname{cov}\left(R_{i t}, M_{i t}\right)}{\operatorname{var}\left(M_{i t}\right)}=\frac{\operatorname{var}\left(E\left(M_{i t}\right)\right)}{\operatorname{var}\left(E\left(M_{i t}\right)\right)+\operatorname{var}\left(\varepsilon_{i t}^{M}\right)} \beta$. A similar bias may exist where government subsidies are not known with certainty when rents are being determined. A number of approaches could be applied to overcome this expectation error bias. Firstly, one could seek a variable that captures expectations directly (e.g. Kirwan and Roberts, 2010). Secondly, if one knows the extent of expectation bias from some other source, then an adjustment to the realised variable could be made. A third approach, and that which is taken in this paper (as well as much of the recent literature), is to use an instrumental variable (IV) 12 | P a g e 
approach whereby variables that are correlated with realised returns but are not correlated with the expectation error are used as instruments for the realised values (Roberts et al., 2003; Lence and Mishra, 2003; Hendricks et al., 2012 and Patton et al., 2008 inter alia).

However, expectation error is not the only complication that arises when using estimates of equation [3] to identify the capitalization of agricultural subsidies into rental rates. Unobserved heterogeneity, if ignored, will result in serial correlation, since $\mu_{\mathrm{i}}$ is time invariant and unobserved, and will also bias the estimated coefficients if $\mu_{\mathrm{i}}$ is correlated with the explanatory variables. Furthermore, correlation between the lag $\left(\mathrm{R}_{\mathrm{it}-1}\right)$ and $\mu_{\mathrm{i}}$ will lead $\gamma$ to be overestimated in an OLS regression and will cause standard errors to be inconsistent (Arellano and Bond, 1991). On the other hand Nickell (1981) shows that the within transformation (i.e. Fixed effects or LSDV estimator) also leads to bias in this context. ${ }^{8}$ One approach to deal with this problem is to transform the data by differencing or using forward orthogonal deviations (Arellano and Bover, 1995) to remove the $\mu_{\mathrm{i} .}{ }^{9}$ Differencing the data, we obtain the following model:

$$
\Delta R_{i t}=\gamma \Delta R_{i t-1}+\beta \Delta E M_{i t}+\omega \Delta G_{i t}+\Delta v_{i t}
$$

However $\Delta R_{i t-1}\left(=\mathrm{R}_{\mathrm{it}-1}-\mathrm{R}_{\mathrm{it}-2}\right)$ is correlated with $\Delta v_{i t}=v_{i t}-v_{i t-1}$, since $\mathrm{R}_{\mathrm{it}-1}$ is a function of $v_{i t}$, meaning that OLS on first-differences is not consistent - essentially differencing the data has introduced endogeneity. Within a GMM framework (Holtz-Eakin, Newey, and Rosen, 1998), the system GMM estimator has been proposed to deal with such endogeneity in

\footnotetext{
${ }^{8}$ Whilst estimating [2] using OLS offers an upper bound estimate for $\gamma$, the within (i.e. fixed effects) estimator tends to underestimate $\gamma$ (in short panels) offering some guidance for where the true value should lie (Bond, 2002). These estimates are shown in Table A3.

${ }^{9}$ Demeaning the data would also remove $\mu_{\mathrm{i}}$. However this is unattractive since the demeaned error term would be correlated with lags of the explanatory variable.
}

13 | P a g e 
dynamic models (Arellano and Bond, 1991; Blundell and Bond, 1998).10 This approach uses lagged differences of the endogenous variables as instruments for the variables in addition to using the levels as instruments for their differences.

In one-step GMM an arbitrary choice is made about the variance-covariance matrix for the errors $(\Omega)$, e.g. homoskedasticity, providing a consistent estimator of $\beta$. In two-step GMM the residuals can be obtained using the one-step estimator and are used to estimate the variancecovariance matrix $\left(\widehat{\Omega}_{\beta_{1}}\right)$. The two-step GMM estimator is thus:

$$
\hat{\beta}=\left(X^{\prime} Z\left(Z^{\prime} \hat{\Omega}_{\beta_{1}} Z\right)^{-1} Z^{\prime} X\right)^{-1}\left(X^{\prime} Z\left(Z^{\prime} \hat{\Omega}_{\beta_{1}} Z\right)^{-1} Z^{\prime} Y\right)
$$

where $\mathrm{X}$ is a matrix of explanatory variables, $\mathrm{Z}$ is a matrix of instruments and $\mathrm{Y}$ is a vector of containing the dependent variable for each individual. This two-step estimator suffers from downward bias in the standard errors, however we apply the correction suggested by Windmeijer (2005) to reduce this small-sample bias.

Time dummies are included to allow for universal period-specific shocks which may violate the assumption that errors are correlated only within individuals and not across them (Roodman, 2009). While first order autocorrelation is likely to be present by construction since $\Delta v_{i t}$ and $\Delta v_{i t-1}$ both include $v_{i t-1}$, higher order serial correlation would render some lags invalid as instruments. Arellano and Bond (1991) have developed a test for serial correlation in the idiosyncratic errors in the differenced equation and we report these results below. Sargan (1958) offers a means to test the exogeneity of the chosen instruments if the

\footnotetext{
${ }^{10}$ This approach requires an additional assumption that the change in rents is not correlated with time-invariant unobserved heterogeneity $\left(\mu_{\mathrm{i}}\right)$
}

14 | P a g e 
model is over-identified and the errors are assumed to be homoskedastic. ${ }^{11}$ Hansen (1982) generalises this test to allow for heteroskedastic errors and we report these test results below. The system-GMM framework allows us to instrument market returns and subsidies using their lags to overcome expectation error.

Two further statistical issues warrant discussion. Firstly, the Teagasc NFS does not geo-code farms so it is not possible to explore spatial correlation. Secondly, since the farms present in the NFS that rent land may not be representative of non-renting farms, the estimates provided here should not be taken as an estimate of the capitalization that would occur on non-renting farms if they chose to rent. Selection bias has generally been implicitly assumed to be absent in much of the literature, exceptions are Moro et al. (2013) and Ciaian and Kancs (2012) who explore selection bias in static models.12 Unfortunately, a method capable of addressing dynamics, endogeneity and selection bias has not yet been proposed in the methodological literature. Here, we assume that there is no selection bias in line with most of the existing literature. While Table A4, indicates that subsidies tend to be higher for renting farms than for non-renting farms (albeit not statistically significantly in many cases), this would be anticipated to lead to positive selection bias, overstating capitalization. Therefore our estimates are likely to represent conservative estimates of the capitalization of subsidies into land rents. ${ }^{13}$

\footnotetext{
${ }^{11}$ The use of multiple lags as instruments means that in GMM models are generally over-identified.

${ }^{12}$ Moro et al. (2013) adopt an approach developed by Semykina and Wooldridge that deals with selection bias and endogeneity, however this approach is only valid for static panels. Although Semykina and Wooldridge (2013) have also advanced an approach to deal with selection bias in a dynamic panel context, their approach is not valid when the explanatory variables are endogenous as is the case here. The authors thank Professor Semykina for helpful comments regarding this point.

${ }^{13}$ The authors thank an anonymous reviewer for highlighting this point.
}

15 | P a g e 


\section{Data}

Each year, the Teagasc National Farm Survey (NFS) of approximately 1,200 Irish farmers is conducted. ${ }^{14}$ The survey data is nationally representative of Irish dairy, cattle, sheep and tillage farmers. Although the Teagasc NFS does not contain data on the rental rate paid for particular parcels of land, it does contain information on the total amount of rent paid and the total area rented in, allowing the calculation of an average rental rate per hectare rentedin. Ideally the dataset would contain information on market returns and subsidies specific to the area rented in, however such detailed data are not available. Facing similar data shortcomings, authors including Ciaian and Kancs (2012) use average values per hectare farmed in place of average values per hectare rented and we do likewise. A further consideration is that subsidies only accrue to the eligible hectares rather than the total number of hectares farmed. In Ireland, subsidies are claimed on the vast majority of eligible land. For instance, we find that there are Single Payment Scheme (SPS) Entitlements on approximately $95 \%$ of the farmed area here, supporting our use of subsidies per hectare farmed. In Ireland it is not uncommon for farmers to rent land from family members for nominal amounts. Therefore rents of less than 20 euro per hectare are considered to be unreliable reflections of the true rental cost of land $(n=45)$ and hence are excluded from the analysis. A small number of farms report implausibly high subsidies or market incomes per hectare $^{15}$ (e.g. 2000 euro per hectare) which would bias results so, in order to prevent this

\footnotetext{
${ }^{14}$ The Teagasc NFS is part of the Farm Accountancy Data Network (FADN) of the European Union (EU).

${ }^{15}$ Market income is calculated by subtracting costs (excluding rents) and subsidies from total farm income. If rents were not subtracted there would negative correlation between market income and rents introduced bias into our estimates.
}

16 | P a g e 
bias, a small number of farms that report values greater than 3 standard deviation from the mean for any of the key explanatory variables or rent per hectare are also excluded $(n=103)$.

We separate subsidies into Pillar 1 and Pillar 2 payments. Prior to 2005, Pillar 1 subsidies were coupled to production, while post-2005 these subsidies were replaced with the SPS and hence were decoupled from production. ${ }^{16}$ Pillar 2 payments are intended to support rural development and environmental protection and place limitations on the activities farms can pursue, hence they may still influence production decisions by constraining the intensity of the agricultural activities practiced. The model is estimated separately for the pre-decoupling and post-decoupling periods using an unbalanced panel of 10,890 observations for 2,082 farms. Figures A1 to A4 in the appendix illustrate the distribution of the key explanatory variables for each system by year.

\section{Results}

Figure 1 illustrates that the average rental rate per hectare declined substantially in the years preceding the shift to decoupled payments in 2005 but has remained relatively constant since 2005. Figure A5 displays the average income per hectare obtained from Pillar 1 subsidies, Pillar 2 subsidies and via the market for each year in our sample. Only dairy and tillage farms on average earn positive market returns while cattle and sheep farms on average are loss making in the absence of subsidies. There is also a clear distinction in the extent to which the farms tend to be reliant on subsidies, with tillage farms tending to receive a smaller proportion of their incomes from Pillar 2 subsidies.

\footnotetext{
${ }^{16}$ O'Neill and Hanrahan (2012) provide more details on the implementation of the Single Payment Scheme in Ireland. 17 I P a g e
} 
Table 1 presents the results for the pre- and post-decoupling periods using the two-step System-GMM estimator applying the Windmeijer correction for small sample bias and a full set of year dummies. We use the second lags of rents, market income, Pillar 1 and Pillar 2 subsidies as instruments in the differenced equation and the lagged change in these variables as instruments in the levels equation. ${ }^{17}$

Tables A1 and A2 in the appendix display results including additional control variables such as soil quality, age, whether the farmer has an off-farm job and the value of the farm. These variables were not found to be important determinants of rental rates and hence were excluded from the final analysis. The insignificance of such variables is not so surprising since after conditioning on market income and subsidies one would anticipate that the impact of soil quality is largely accounted for since it's influence operates chiefly through increasing the productivity and hence income, of the plot. Hansen tests for the validity of instruments, also reported in Table 1, suggest that the instruments are exogenous as required.

Lagged rents are strongly related to current rents albeit slightly less so following decoupling. In the pre-decoupling period, approximately 6 cents per euro of market income is capitalized into land rents for dairy farms in the short term which corresponds to approximately 30 cents per euro in the long run. Positive effects of market income on agricultural rent levels are found for the other systems but these coefficients are not found to be statistically significant. Turning to Pillar 1 payments, area aid payments, such as those to tillage farmers, act as a land cost subsidy and hence are expected to lead to greater capitalization than

\footnotetext{
${ }^{17}$ Figures A6 and A7 explore the impact of using deeper lags as additional instruments on the estimated long run incidence.
}

18 | P a g e 
output subsidies such as those for cattle and sheep (Kilian et al, 2012; Alston and James, 2001; Guyomard et al., 2004). Our findings for the pre-decoupling period are consistent with this hypothesis, for dairy farms 15 cents (77 cents) of each euro of payments are capitalized into land rents in the short (long) run. For sheep and tillage farms the corresponding figures are 25 cents (67 cents) and 32 cents (89 cents). For cattle farms, Pillar 1 payments do not appear to be capitalized into rents in the pre-decoupling period although this can be attributed to the imprecision of the estimate. Pillar 2 payments are not capitalized into land rents which may in part be due to the nature of these payments and the relatively small contribution they make to total income per hectare (see Figure A5). For instance one of the major components of Pillar 2 payments in Ireland are made under the agri-environmental measure applied in Ireland known as the Rural Environment Protection Scheme (REPS) and can only be received on rented land if the farmer can prove that they have rented the land for a period in excess of the subsidy program contract period. Given the prevalence of short-term "conacre" rental contracts this effectively restricts these payments to owned land in Ireland. In the post-decoupling period, we find that market returns for dairy and tillage farms are not capitalized into rents but that surprisingly for cattle and sheep farms higher market incomes are associated with lower rental rates, albeit insignificantly so in the case of sheep farms.

Prior to decoupling, Irish farmers are known to have engaged in activities intended to maximise subsidy receipts, commonly referred to as "farming the subsidy" (Breen et al, 2005; McDonald et al, 2014). Many Irish farms, particularly livestock farms, are not economically viable in the absence of subsidies (see Figure A5). This may explain the relative unimportance of market returns in the pre-decoupling period. While the move to decoupled 19| P a g e 
payments would be anticipated to lead farmers to be more market oriented, this does not appear to have happened. Howley et al. (2012) also provide evidence that farmers have used decoupled subsidies to subsidise loss-making activities. One explanation may be that farmers may anticipate that the reference period for decoupled payments will be updated to include the current period, meaning future decoupled payments may depend on behaviour in the current period. Howley (2015) highlights the tendency for Irish farmers to focus on nonpecuniary benefits when making decisions which may be an alternative explanation for the relative unimportance of market returns in determining rental rates.

Pillar 1 payments remain capitalized into land rents, albeit in most cases slightly less so although for cattle farms capitalization increases to 7 cents (21 cents) per euro of support in the short (long) run. For dairy farms 12 cents (41 cents) per euro of support and for tillage farms 25 cents (53 cents) per euro of support were capitalized in the short (long) run. For sheep farms the capitalization fell to 9 cents (35 cents) and is not significantly different from zero. This reduction in capitalization is in line with theoretical work such as Michalek et al. (2014) who argue that the degree of capitalization depends on the ratio between the number of entitlements and the hectares of eligible area since the consolidation option in Ireland reduced the number of entitlements.

Figure 2 graphically presents the estimated long run capitalization and its corresponding 95\% confidence interval for both the pre- and post-decoupling periods. For the predecoupled period, we cannot reject the null hypothesis that Pillar 1 payments are fully capitalized into land rents for dairy, cattle and tillage farms while for sheep farms there is also a high degree of capitalization. For cattle farms estimates are very imprecise with the 20| Pag e 
confidence interval spanning both full capitalization and also zero capitalization. ${ }^{18}$ The results suggest that capitalization of Pillar 1 subsidies has fallen post-decoupling, however, since the confidence intervals pre- and post-decoupling overlap for all systems except Tillage we cannot conclusively say that this is the case, primarily due to the imprecision of predecoupling estimates.

\section{Conclusions:}

The influence of subsidies on land prices has attracted considerable attention in the literature. More recently attention has focussed on land rental rates. This paper explores the extent to which coupled and decoupled subsidy payments have been capitalized into land rental rates in Ireland. Prior to decoupling, we find that Pillar 1 payments are heavily capitalized into land rents, reducing the transfer efficiency of these payments. Indeed we cannot reject the possibility that particularly for dairy and tillage farms, the entirety of these subsidies accrue to landowners over time in the form of higher rents. Following the Fischler reforms to CAP, the degree to which pillar 1 subsidies are bid into agricultural land rents has declined. This may be explained by the interaction between the reforms themselves and the prevailing agricultural rental market custom in Ireland, i.e. the conacre short term rental model. The freedom to consolidate entitlement values accorded to farmers who in the reference period farmed rented in land would appear to reduce the extent to which agricultural subsidies are capitalized into agricultural rents. However, this effect was not as

\footnotetext{
${ }^{18}$ Using deeper lags reduces this uncertainty and suggests Pillar 1 subsidies are heavily, but not fully capitalized. See Figure $A 5$ and $A 6$ in appendix.

21 I P a g e
} 
dramatic as one might anticipate, in line with the conclusions of O'Neill and Hanrahan (2012) who found that the reform did not dramatically influence the area rented by farms in Ireland.

A priori, given the short term nature of agricultural land rental contracts in Ireland, one would expect to observe less inertia in Irish agricultural rents than in other European countries where longer term rental contracts are the norm (Ciaian et al., 2012). However, the estimated coefficient on the lagged rents variable ranged from 0.532 to 0.886 . These results reveal the importance of accounting for inertia in the agricultural land rent-setting process, even where $a$ priori one may not strongly anticipate this being an issue. This may be due to search costs when seeking alternative plots to rent or significant transaction costs. In Ireland land is often rented within the locality of the farm, limiting competition and increasing the importance of social relations between the landlord and tenant.

Given the importance of past rents in determining current rents, it is not surprising that other variables are found to play a lesser role. While market income and Pillar 2 payments tends to have a weak impact on rental rates, in the pre-decoupling period Pillar 1 subsidies for dairy, sheep and tillage farms are found to be heavily capitalized into agricultural land rents, with Pillar I subsidy capitalization rates ranging from 67 to 90 cents per euro of subsidies. Long run capitalization of agricultural subsidies into agricultural rents is highest amongst tillage farms. This system is also in an Irish context the system where the greatest proportion of agricultural area farmed is rented-in land. Post-decoupling, Pillar 1 payments remain capitalized into land rents, albeit in most cases slightly less so than in the pre-decoupling period. The estimated long run capitalization rates for each farm type tend to be approximately half the rate observed for the pre-decoupling periods. This result is attributed 22 P a g e 
to the option for Irish farmers to consolidate their entitlements from rented land where the rental contract has expired to other plots of land, reducing the ability of landowners to capture these payments.

The freedom to consolidate SPS entitlements would appear from the results to have, in an Irish context, reduced the extent to which subsidies are capitalized into rents. This outcome may be peculiar to Ireland, the conacre rental model is only widely used in one other region of the EU, Northern Ireland. The prevalence of long term agricultural land rental contracts in most EU Member States means that the ability of farmers (as opposed to landlords) in other Member States to capture more of the decoupled agricultural subsidy may not have been similarly enhanced by the Fischler reforms. In an Irish context the results suggest that the transfer efficiency of agricultural policy has been improved by the implementation of the Fischler reforms and particularly the freedom to consolidate SPS entitlements that, in the reference period, were "earned" on rented-in land. In an Irish context owned, as opposed to rented, land is the dominant form of land tenure. The relative unimportance of rented land in total agricultural land use (see Ciaian et al., for comparative EU statistics) and very slow rate of structural change in Irish agricultural suggest that in the future structural change in Irish agriculture may depend on growth in the share of agricultural area that is rented-in. In the context of the recently agreed reforms to the CAP (EC, 2013) that link entitlement to direct income support to control of agricultural land, the future transfer efficiency of agricultural policy may be reduced if a mechanism that allows farmers to circumvent the capitalization of subsidies into agricultural rents, such as the freedom to consolidate entitlements, is not present.

23 | P a g e 


\section{References:}

Alston, J.M., James, J.S., 2002. The incidence of agricultural policy. In: Gardner, B.L., Rausser, G.C. (Eds.), Agricultural and food policy. Handbook of Agricultural Economics, vol. 2B. NorthHolland, Amsterdam.

Arellano, M., Bond, S.R., 1991. Some tests of specification for panel data: Monte Carlo evidence and an application to employment equations. Rev. Econ. Stud. 58, 277-297.

Anderson, T.W., Hsiao C., 1981. Estimation of dynamic models with error components. J. Am. Stat. Assoc. 589-606.

Arellano, M. Bover, O., 1995. Another look at the instrumental-variable estimation of error components models. J. Econometrics, 68, 29-52.

Barnard, C.H., Whittaker, G., Westenbarger, D. Ahearn, M., 1997. Evidence of Capitalization of Direct Government Payments into U.S. Cropland Values. Am. J. Agr. Econ. 79, 1642-1650.

Blundell, R., Bond, S., 1998. Initial conditions and moment restrictions in dynamic panel data models. J. Econometrics, 87, 115-143.

Bond, S., 2002. Dynamic panel data models: A guide to micro data methods and practice. Working Paper 09/02. Institute for Fiscal Studies. London.

Breustedt, G., Habermann, H., 2011. The Incidence of EU Per-Hectare Payments on Farmland Rental Rates: A Spatial Econometric Analysis of German Farm-Level Data. J. Agr. Econ. 62, $225-243$.

Breen J.P., Hennessy T.C., Thorne F.S., 2005. The Effect of Decoupling on the Decision to Produce: An Irish Case Study. Food Policy, 30, 129-114.

24 | P a g e 
Ciaian, P., Kancs, D., 2012. The Capitalization of Area Payments into Farmland Rents: Micro Evidence from the New EU Member States. Can. J. Agr. Econ. 60(4), 517-540.

Ciaian, P., Kancs, D. Michalek, J., 2011. SPS Capitalization into Land Value: Generalized Propensity Score Evidence from the EU. LICOS Discussion Paper No. 293, Leuven : LICOS Centre for Institutions and Economic Performance.

Ciaian, P. Swinnen, J.F.M., 2006. Land Market Imperfections and Agricultural Policy Impacts in the New EU Member States: A Partial Equilibrium Analysis. Am. J. Agr. Econ. 88, 799-815.

Childs, N., 2001. Rice: Background and Issues for Farm Legislation. Electronic Outlook Report RCS-0601-01 from the Economic Research Service (ERS) of the United States Department of Agriculture (USDA), July.

Courleux, F., Guyomard, H., Levert, F., Piet, L, 2008. How the EU Single Farm Payment should be modelled: lump-sum transfers, area payments or... what else? Working Paper SMART LERECO Nº8-01.

DAF, 2004. The single payment scheme: an explanatory guide. Department of Agriculture and Food, Dublin.

European Commission, 2012. Overview of the implementation of direct payments under the CAP in Member States in 2012 (Reg. 73/2009) http://ec.europa.eu/agriculture/directsupport/pdf/implementation-direct-payments_en.pdf (last accessed: 2nd October 2013) 
European Commission, 2013. CAP Reform - An explanation of the main elements" European Commission - MEMO/13/621, 26/06/2013. http://europa.eu/rapid/press-release MEMO13-621 en.htm (last accessed 7 October, 2013)

Featherstone, A.M., Baker, T.G., 1987. An Examination of Farm Sector Real Asset Dynamics: 1910-85. Am. J. Agr. Econ. 69(3), 532-546.

Floyd, J.E., 1965. The Effects of Farm Price Supports on the Return to Land and Labor in Agriculture. J. Polit. Econ. 73(2), 148-58.

Fuchs, C., 2002. The influence of per-hectare premiums on prices for rented agricultural area and on agricultural land prices. Agrarwirtschaft, 51(8), 396-404.

Guastella, G., Moro, D., Sckokai, P., Veneziani, M., 2013. The Capitalization of Area Payment into Land Rental Prices: Micro-evidence from Italy, 2013 Annual Meeting, August 4-6, 2013, Washington, D.C. 150617, Agricultural and Applied Economics Association.

Guyomard, H., Bureau, J.C., Gohin, A., Le Mouël, C., 2000. Impact of the 1996 US FAIR Act on the Common Agricultural Policy in the World Trade Organisation context: the decoupling issue. Food Policy, 25(1), 17-34.

Guyomard, H., Le Mouël, C., Gohin, A., 2004. Impacts of alternative agricultural income support schemes on multiple policy goals. Eur. Rev. Agric. Econ. 31(2), 125-148.

Hansen, L.P., 1982. Large sample properties of generalized method of moments estimators. Econometrica, 50(4), 1029-1054. 
Hendricks, N., Janzen, J., Dhuyvetter, K., 2012. Subsidy Incidence and Inertia in Farmland Rental Markets: Estimates from a Dynamic Panel. J. Agr. Resour. Econ. 37(3), 361-378.

Hennessy, D.A., 1998. The Production Effects of Agricultural Income Support Polices under Uncertainty. Am. J. Agr. Econ. 80(1), 46-57.

Hertel, T.W., 1989. Negotiating Reductions in Agricultural Support: Implications of Technology and Factor Mobility. Am. J. Agr. Econ., 71(3), 559-573.

Holtz-Eakin, D., Newey, W., Rosen, H. S., 1988. Estimating vector autoregressions with panel data. Econometrica, 56(6), 1371 - 1395.

Howley, P., Breen, J., Donoghue, C., Hennessy, T., 2012. Does the single farm payment affect farmers' behaviour? A macro and micro analysis. Int. J. Agr. Manag. 2 (1), 57-64(8).

Howley, P., 2015. The Happy Farmer: The Effect of Nonpecuniary Benefits on Behavior. Am. J. Agr. Econ. 97(4), 1072-1086.

Karlsson, J., Nilsson, P., 2014. Capitalization of Single Farm Payment on farm price: an analysis of Swedish farm prices using farm-level data. Eur. Rev.Agric. Econ. 41 (2), 279-300.

Kilian, S, Anton, J., Salhofer, K., Roeder, N., 2012. Impacts of 2003 CAP reform on land rental prices and capitalization. Land Use Policy, 29(4), 789-797.

Kirwan, B., 2005. Essays on U.S. Agricultural Policy: Subsidies, Crop Insurance, and Environmental Auctions. PhD dissertation, Massachusetts Institute of Technology, 2005. Accessed 17th September 2013: dspace.mit.edu/handle/1721.1/3383. 
Kirwan, B., 2009. The Incidence of U.S. Agricultural Subsidies on Farmland Rental Rates. J. Polit. Econ., 117(1), 138-164.

Kirwan, B., Roberts, M.J., 2010. Who Really Benefits from Agricultural Subsidies?

Evidence from Field-Level Data. Selected Paper Agricultural \& Applied Economics Association AAEA, CAES, \& WAEA Joint Annual Meeting, July 25-27, Denver, Colorado.

Kroll, J-C., 2008. The implementation of single payment schemes in European Union countries, Paper prepared for the 109th EAAE Seminar "The CAP after the Fischler reform: national implementations, impact assessment and the agenda for future reforms", Viterbo, November 20-21.

Latruffe, L., Le Mouël, C. 2009. Capitalization of Government Support in Agricultural Land Prices: What Do We Know? J. Econ. Surv. 23(4), 659-691.

Lence, S.H., Mishra, A.K., 2003. The Impacts of Different Farm Programs on Cash Rents. Am. J. Agr. Econ., 85(3), 753-761.

McDonald, R., Macken-Walsh, Á., Pierce, K., Horan, B., 2014. Farmers in a deregulated dairy regime: Insights from Ireland's New Entrants Scheme. Land Use Policy, 41, 21-30.

Michalek, J., Ciaian, P., Kancs, D., 2014. Capitalization of the Single Payment Scheme into Land Value: Generalized Propensity Score Evidence from the European Union. Land Economics, 90(2), 260-289.

Nickell, S.J., 1981. Biases in dynamic models with fixed effects. Econometrica, 49(6), 14171426.

O'Neill, S.,Hanrahan, K., 2012. Decoupling of agricultural support payments: the 28 | $P$ a g e 
impact on land market participation decisions. Eur. Rev. Agric. Econ. 39(4), 639-659.

Organisation for Economic Co-operation and Development. (OECD), 2001. Decoupling: A Conceptual Overview. Paris: OECD.

Patton, M., Kostov, P., McErlean, S., Moss, J., 2008. Assessing the influence of direct payments on the rental value of agricultural land. Food Policy, 33(5), 397-405.

Phipps, T.T., 1984. Land Prices and Farm-Based Returns. Am. J. Agr. Econ. 66(4), 422-429.

Qiu, F., Gervais, J.P., Goodwin, B.K., 2010. An Empirical Investigation of the Impacts of Government Subsidies on Farmland Rental Rates. paper prepared for the 2010 Agricultural and Applied Economics Association annual meeting, Denver, Colorado, 25-27 July 2010.

Roodman, D., 2009. How to do xtabond2: An introduction to difference and system GMM in Stata. Stata Journal, 9(1), 86-136.

Roberts, M.J., Kirwan, B., Hopkins, J., 2003. The Incidence of Government Program Payments on Agricultural Land Rents: The Challenges of Identification. Am. J. Agr. Econ. 85(3), 762-769.

Rude, J., 2000. An Examination of Nearly Green Programs: Case Study for Canada. Am. J. Agr. Econ. 82 (3), 755-761.

Sargan, J.D., 1958. The estimation of economic relationships using instrumental variables.

Econometrica, 26(3), 393-415.

Semykina, A., Wooldridge, J.M., 2010. Estimating panel data models in the presence of endogeneity and selection. J. Econometrics, 157(2), 375-380.

29 | $P$ a g e 
Semykina, A., Wooldridge, J.M., 2013. Estimation of Dynamic Panel Data Models with Sample Selection. J. Appl. Econom. 28(1), 47-61.

Shaik, S., Helmers, G.A., Atwood, J.A., 2005. The Evolution of Farm Programs and Their Contribution to Agricultural Land Values. Am. J. Agr. Econ. 87(5), 1190-1197.

Sumner D.A., 2003. Implications of the US Farm Bill of 2002 for agricultural trade and trade negotiations. Aust. J. Agr. Resour. Ec. 46(3), 99-122.

Sumner, D.A., 2007. Farm Subsidy Tradition and Modern Agricultural Realities. Working Paper, American Enterprise Institute Policy Series: The 2007 Farm Bill and Beyond. Washington, D.C.: AEI Press.

Swinbank, A., Tangermann, S., 2001. The Future of Direct Payments Under the CAP: A Propoal. EuroChoices, 1(1), 28-29.

Swinbank, A., Tangermann, S., 2004. A Bond Scheme to Facilitate CAP Reform, in Swinbank, A. and Tranter, R. (eds.), A Bond Scheme for Common Agricultural Policy Reform, CABI: Wallingford.

Swinbank A., Tranter, R., Daniels, J., Wooldridge, M., 2004. An examination of various theoretical concepts behind decoupling and review of hypothetical and actual decoupled support schemes in some OECD countries. Deliverable D1.1, GENEDEC Project. http://www.grignon.inra.fr/economie-publique/genedec/publi/deliv/GENEDEC_D1_1.pdf Accessed January 11, 2011.

Vercammen, J., 2003. A stochastic dynamic programming model of direct subsidy payments and agricultural investment. Paper presented at the joint annual meeting of the American 30 | P a g e 
Agricultural Economics Association and Canadian Agricultural Economics Society, 27-30 July 2003, Montreal.

Weersink, A., Clark, S., Turvey, C.G., Sarker, R., 1999. The Effect of Agricultural Policy on Farmland Values. Land Econ., 75(3), 425-439.

Westcott, P.C. and Young, C.E., 2002. Influences of decoupled farm programs on agricultural production. Presented at Free Trade Area of the Americas, The WTO, and New Farm Legislation: Responding to Opportunities and Challenges, San Antonio, Texas.

Windmeijer, F., 2005. A finite sample correction for the variance of linear efficient two-step GMM estimators. J. of Econometrics, 126(1), 25-51.

Wooldridge J.M., 1995. Selection corrections for panel data models under conditional mean independence assumptions. J. of Econometrics, 68(1), 115-132.

Woodard, S., Paulson, N.D., Baylis, K., Woodard, J.D., 2010. A Spatial Analysis of Illinois Agricultural Cash Rents. Working paper, Department of Agricultural and Consumer Economics, University of Illinois at Urbana-Champaign.

31 I P a g e 
Figure 1: Average rent per hectare by farm system:

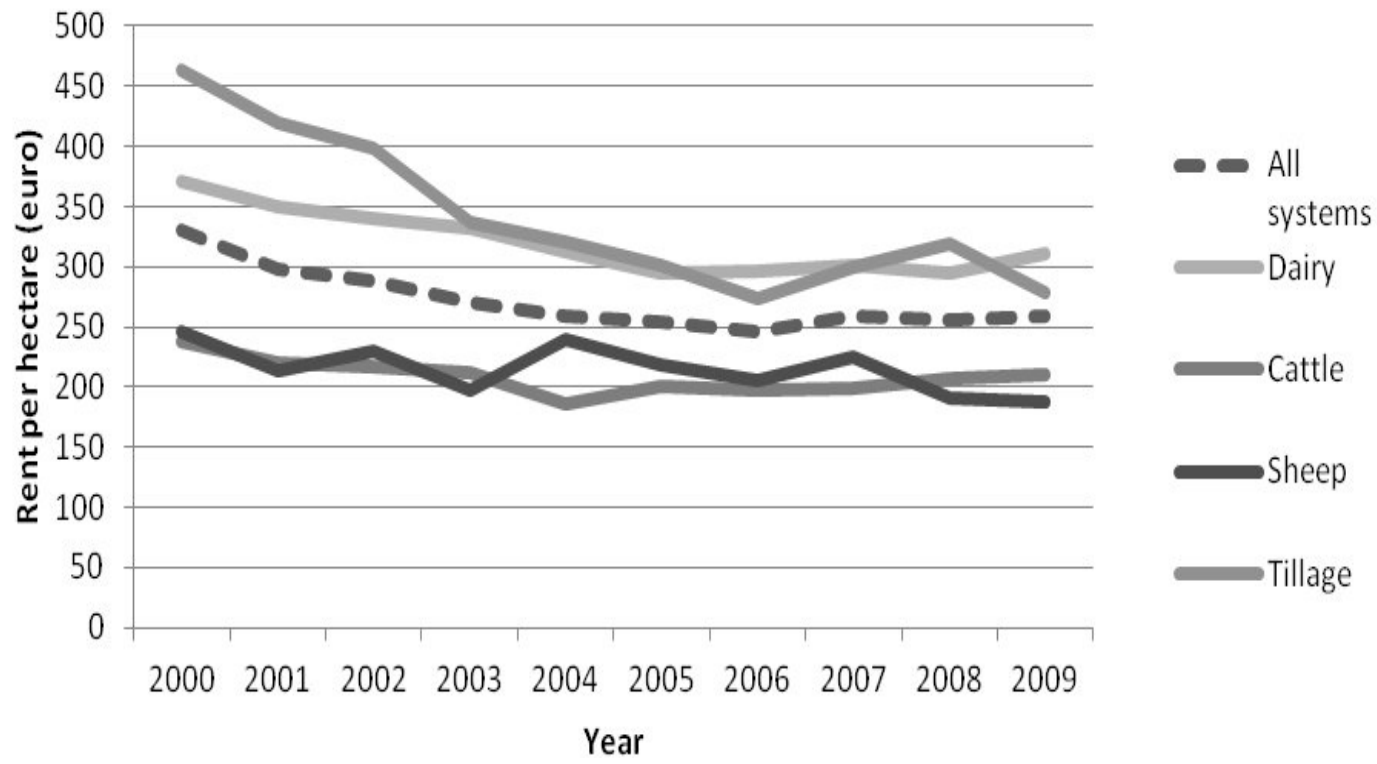

Figure 2: Long run capitalization of subsidies pre- and post-decoupling:

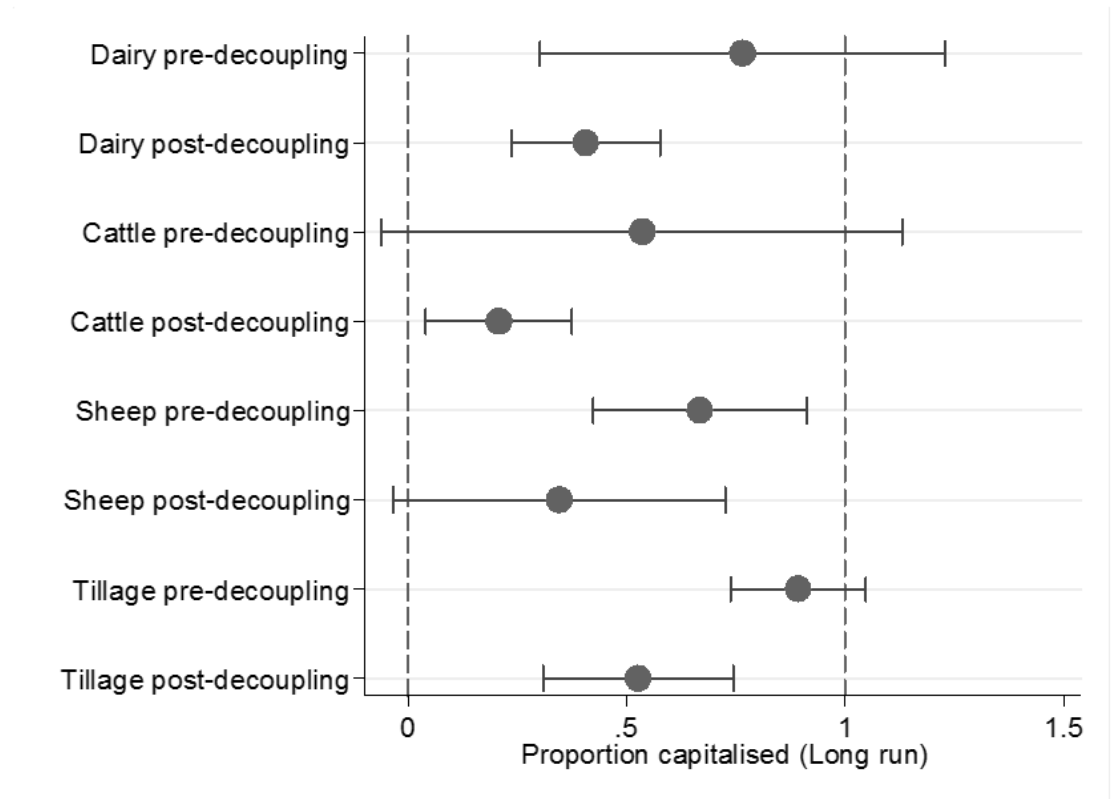

32 | P a g e 
Table 1: Two-step Robust System GMM for pre-decoupling and post-decoupling periods:

\begin{tabular}{|c|c|c|c|c|}
\hline & Dairying & Cattle & Sheep & Tillage \\
\hline \multicolumn{5}{|l|}{ Pre-decoupling } \\
\hline \multirow[t]{2}{*}{ Lagged Rent per hectare } & $0.811^{* * *}$ & $0.886^{* * *}$ & $0.620^{* * *}$ & $0.646^{* * *}$ \\
\hline & $(0.056)$ & $(0.063)$ & $(0.123)$ & $(0.089)$ \\
\hline \multirow[t]{2}{*}{ Market Income per hectare } & $0.056^{* *}$ & 0.059 & 0.069 & 0.048 \\
\hline & $(0.025)$ & $(0.042)$ & $(0.057)$ & $(0.049)$ \\
\hline \multirow[t]{2}{*}{ Pillar 1 payments per hectare } & $0.145^{* *}$ & 0.061 & $0.254^{* * *}$ & $0.316^{* * *}$ \\
\hline & $(0.069)$ & $(0.052)$ & $(0.097)$ & $(0.091)$ \\
\hline \multirow[t]{2}{*}{ Pillar 2 payments per hectare } & 0.103 & 0.163 & -0.012 & -0.069 \\
\hline & $(0.068)$ & $(0.120)$ & $(0.123)$ & $(0.109)$ \\
\hline \multicolumn{5}{|l|}{ Post-Decoupling } \\
\hline \multirow[t]{2}{*}{ Lagged Rent per hectare } & $0.700^{* * *}$ & $0.645^{* * *}$ & $0.735^{* * *}$ & $0.522^{* * *}$ \\
\hline & $(0.069)$ & $(0.088)$ & $(0.129)$ & $(0.137)$ \\
\hline \multirow[t]{2}{*}{ Market Income per hectare } & 0.027 & $-0.083^{*}$ & -0.041 & 0.040 \\
\hline & $(0.025)$ & $(0.045)$ & $(0.085)$ & $(0.035)$ \\
\hline \multirow[t]{2}{*}{ Pillar 1 payments per hectare } & $0.122^{* * *}$ & $0.074^{*}$ & 0.092 & $0.252^{* *}$ \\
\hline & $(0.045)$ & $(0.040)$ & $(0.086)$ & $(0.117)$ \\
\hline \multirow[t]{2}{*}{ Pillar 2 payments per hectare } & 0.129 & 0.073 & 0.045 & 0.091 \\
\hline & $(0.088)$ & $(0.098)$ & $(0.110)$ & $(0.156)$ \\
\hline \multicolumn{5}{|l|}{$\underline{\text { Statistical tests: }}$} \\
\hline \multicolumn{5}{|l|}{ Pre-Decoupling } \\
\hline Hansen p-value & 0.550 & 0.552 & 0.405 & 0.642 \\
\hline AR(1) p-value & $0.0001^{* * *}$ & $0.0001^{* * *}$ & $0.037^{* *}$ & $0.022^{* *}$ \\
\hline AR(2) p-value & 0.454 & 0.267 & 0.124 & 0.782 \\
\hline \multicolumn{5}{|l|}{ Post-Decoupling } \\
\hline Hansen p-value & 0.112 & 0.361 & 0.371 & 0.141 \\
\hline AR(1) p-value & $0.0001^{* * *}$ & $0.019^{* *}$ & $0.055^{*}$ & $0.006^{* * *}$ \\
\hline $\mathrm{AR}(2) \mathrm{p}$-value & 0.540 & 0.358 & 0.725 & 0.265 \\
\hline
\end{tabular}

$* * *=$ significant at $1 \%, * *=$ significant at $5 \%, *=$ significant at 10

33 | P a g e 